\title{
Suppression of Streptozotocin-Induced Type-1 Diabetes in Mice by Radon Inhalation
}

\author{
Y. NISHIYAMA ${ }^{1}$, T. KATAOKA ${ }^{1}$, J. TERAOKA ${ }^{1}$, A. SAKODA ${ }^{2}$, H. TANAKA ${ }^{2}$, \\ Y. ISHIMORI ${ }^{2}$, F. MITSUNOBU ${ }^{3}$, T. TAGUCHI ${ }^{1}$, K. YAMAOKA $^{1}$ \\ ${ }^{1}$ Graduate School of Health Sciences, Okayama University, Okayama-shi, Japan, ${ }^{2}$ Ningyo-toge \\ Environmental Engineering Center, Japan Atomic Energy Agency, Tomata-gun, Japan, ${ }^{3}$ Misasa \\ Medical Center, Okayama University Hospital, Tohaku-gun, Japan
}

Received January 5, 2012

Accepted August 31, 2012

On-line November 22, 2012

\section{Summary}

We examined the protective effect of radon inhalation on streptozotocin (STZ)-induced type-1 diabetes in mice. Mice inhaled radon at concentrations of 1000,2500 , and $5500 \mathrm{~Bq} / \mathrm{m}^{3}$ for 24 hours before STZ administration. STZ administration induced characteristics of type- 1 diabetes such as hyperglycemia and hypoinsulinemia; however, radon inhalation at doses of 1000 and $5500 \mathrm{~Bq} / \mathrm{m}^{3}$ significantly suppressed the elevation of blood glucose in diabetic mice. Serum insulin was significantly higher in mice pre-treated with radon at a dose of $1000 \mathrm{~Bq} / \mathrm{m}^{3}$ than in mice treated with a sham. In addition, superoxide dismutase activities and total glutathione contents were significantly higher and lipid peroxide was significantly lower in mice pre-treated with radon at doses of 1000 and $5500 \mathrm{~Bq} / \mathrm{m}^{3}$ than in mice treated with a sham. These results were consistent with the result that radon inhalation at 1000 and $5500 \mathrm{~Bq} / \mathrm{m}^{3}$ suppressed hyperglycemia. These findings suggested that radon inhalation suppressed STZ-induced type-1 diabetes through the enhancement of antioxidative functions in the pancreas.

\section{Key words}

Radon inhalation • Antioxidative function • Streptozotocin • Type1 diabetes

\section{Corresponding author}

Kiyonori Yamaoka, Graduate School of Health Sciences, Okayama University, 5-1 Shikata-cho 2-chome, Kita-ku, Okayama-shi, Okayama 700-8558, Japan. Fax: +81-86-235-6852. E-mail: yamaoka@md.okayama-u.ac.jp

\section{Introduction}

Free radicals and other reactive oxygen species (ROS) are constantly formed in the human body. Freeradical mechanisms have been implicated in the pathology of several human diseases, such as cancer, atherosclerosis, and malaria (Aruoma 1998). On the other hand, it has been reported that low-dose irradiation induces various biological effects, such as increased resistance to ROS (Kojima et al. 1997) and enhanced immune function (Ishii et al. 1995, Kojima et al. 2004). We have reported that low-dose $\mathrm{X}$ - or $\gamma$-irradiation increases or induces antioxidant substances such as superoxide dismutase (SOD) (Yamaoka et al. 1991, Yamaoka et al. 1999), catalase (CAT) (Kojima et al. 1999), and glutathione (GSH) (Kojima et al. 2004) in some organs of small animals. These findings indicate that low-dose irradiation may contribute to preventing or alleviating ROS-related injury (Yamaoka 2006). In fact, we previously reported that low-dose X-irradiation inhibited oxidative damage, such as brain edema (Yoshimoto et al. 2012), ischemia-reperfusion injury (Kataoka et al. 2007), and carbon tetrachloride $\left(\mathrm{CCl}_{4}\right)$ induced hepatopathy in mice (Kataoka et al. 2005, Yamaoka et al. 2004a).

Therapy using radon $\left({ }^{222} \mathrm{Rn}\right)$, which is volatilized from radon-enriched water and mainly emits $\alpha$-rays, is performed for ROS-related diseases, such as arteriosclerosis, osteoarthritis (Yamaoka et al. 2004b), and bronchial asthma (Mitsunobu et al. 2003) at Misasa Medical Center, Okayama University Hospital; however, 
the mechanisms of the therapy have not been fully understood. To clarify the effects of the therapy, we investigated the effects of radon inhalation on mice. We previously reported that radon inhalation increased antioxidant substances and inhibited $\mathrm{CCl}_{4}$-induced hepatopathy (Kataoka et al. 2012) and renal damage (Kataoka et al. 2011a, Nishiyama et al. 2012). These findings suggested that radon inhalation has antioxidative effects similar to low-dose X- or $\gamma$-irradiation.

Diabetes mellitus is now a worldwide disease and, in particular, the number of young patients is increasing (Harjutsato et al. 2008, Mayer-Davis et al. 2009). The $\beta$ cells in the pancreas are susceptible to ROS because they express very low levels of antioxidants (Lenzen et al. 1996); therefore, it is considered that $\beta$ cells are easily subjected to oxidative stress. It is well known that oxidative stress caused by ROS contributes to $\beta$ cell death or dysfunction of the pancreas in type-1 diabetes (Cnop et al. 2005). On the other hand, we recently reported that radon inhalation activated SOD activity in various organs, including the pancreas of mice (Kataoka et al. 2011b), suggesting that radon inhalation may prevent type-1 diabetes; however, there has been no report of a protective effect of radon inhalation on type-1 diabetes.

Streptozotocin (STZ) is widely used in studies of experimental type-1 diabetes because it selectively destroys pancreatic $\beta$ cells through the generation of ROS and alkylation of deoxyribonucleic acid (DNA) (Lenzen 2008, Szkudelski 2001). To assess the protective effect of radon inhalation on STZ-induced type-1 diabetes, we examined the following antioxidant- and diabetesassociated parameters and histological changes of the pancreas: SOD activity, CAT activity, total glutathione ( $\mathrm{t}$ GSH) content, lipid peroxide (LPO), blood glucose, serum insulin, and body weight.

\section{Methods}

\section{Animals}

Male C57BL/6J mice ( 9 weeks of age, body weight 25-28 g) were purchased from CLEA Japan Inc. (Tokyo, Japan). The animals were housed in clear plastic cages with wood-chip bedding in a temperaturecontrolled room $\left(20 \pm 1^{\circ} \mathrm{C}\right)$. They were fed Oriental MF diet (Oriental Yeast Co., Tokyo, Japan) and tap water $a d$ libitum. Each group consisted of 5-8 mice. Ethics approval was obtained from the animal experimental committee of Okayama University.

\section{Radon inhalation}

Mice were exposed to radon using a large-scale facility developed at Misasa Medical Center, Okayama University Hospital (Ishimori et al. 2010). Briefly, it was designed to examine a number of animals at various radon concentrations at the same time, and the facility has adopted a whole-body exposure system. Air with radon was blown into an exposure box and then blown out of the box. The radon concentration was measured using a radon monitor (Genitron Co., Ltd., Germany).

\section{Experimental procedure}

Mice were divided into eight groups: control (Control), radon inhalation only $(1000,2500$, and 5500 $\mathrm{Bq} / \mathrm{m}^{3}$ ), sham inhalation with STZ administration (Sham + STZ), and radon inhalation with STZ administration $\left(1000 \mathrm{~Bq} / \mathrm{m}^{3}+\mathrm{STZ}, 2500 \mathrm{~Bq} / \mathrm{m}^{3}+\mathrm{STZ}\right.$, and $5500 \mathrm{~Bq} / \mathrm{m}^{3}$ + STZ). Mice were exposed to radon at doses of 1000 , 2500 , and $5500 \mathrm{~Bq} / \mathrm{m}^{3}$ for 24 hours. A single high-dose of STZ (200 mg/kg weight, $50 \mathrm{~g} / \mathrm{l}$ in saline solution) was administrated into the peritoneum immediately after radon inhalation. A single dose of STZ causes mild to severe types of diabetes according to the dosage used. A single high dose of STZ ( $200 \mathrm{mg} / \mathrm{kg}$ weight) destroys most of the $\beta$ cells present in the islets and induces a rapid and permanent insulin-dependent diabetic condition in C57BL strain mice (Shertzer et al. 2009). On the other hand, it has been reported that a single low dose of STZ (approximately $100 \mathrm{mg} / \mathrm{kg}$ weight) sometimes causes a non-insulin-dependent diabetic condition (such as type 2 diabetes) in some strains of mice because the dose level is not sufficient to destroy most of the $\beta$ cells (Ito et al. 2001); therefore, we injected a single high dose of STZ into C57BL strain mice, which are sensitive to the toxicity of STZ and develop complete insulin-dependent type-1 diabetes. Changes in blood glucose and body weight were monitored during the experiment. Blood glucose was measured by Glucose Pilot (Aventir Biotech, LLC, CA, USA) using tail tip blood. Four days after STZ administration, mice were killed by an overdose of ether anesthesia and blood was collected from the heart for analysis of insulin in serum. Serum was obtained by centrifugation at $3,000 \times g$ for $5 \mathrm{~min}$ at $4{ }^{\circ} \mathrm{C}$. The pancreas was quickly excised for SOD, CAT, t-GSH, and LPO analyses. Part of each pancreas was fixed in $10 \%$ formalin for histological examination.

\section{Biochemical assays}

Mouse pancreas was homogenized in $1 \mathrm{M}$ Tris- 
$\mathrm{HCl}$ buffer containing $5 \mathrm{mM}$ ethylenediaminetetraacetic acid (EDTA) ( $\mathrm{pH} 7.4)$ on ice. The homogenate was centrifuged at $12,000 \times g$ for $45 \mathrm{~min}$ at $4{ }^{\circ} \mathrm{C}$ and the supernatant was used for assay of the activity of SOD and CAT. SOD activity was measured by the nitroblue tetrazolium (NBT) reduction method (Baehner et al. 1975) using the Wako-SOD test (Wako Pure Chemical Industry, Co., Ltd., Osaka, Japan). Briefly, the extent of inhibition of the reduction in NBT was measured at $560 \mathrm{~nm}$ using a spectrophotometer. One unit of enzyme activity was defined as $50 \%$ inhibition of NBT reduction.

CAT activity was measured as the hydrogen peroxide $\left(\mathrm{H}_{2} \mathrm{O}_{2}\right)$ reduction rate at $37{ }^{\circ} \mathrm{C}$ and was assayed at $240 \mathrm{~nm}$ using a spectrophotometer (Aebi et al. 1976). The assay mixture consisted of $50 \mu \mathrm{l}$ of $1 \mathrm{M}$ Tris- $\mathrm{HCl}$ buffer containing $5 \mathrm{mM}$ EDTA (pH 7.4), $900 \mu \mathrm{l}$ of $10 \mathrm{mM} \mathrm{H}_{2} \mathrm{O}_{2}, 30 \mu \mathrm{l}$ deionized water, and $20 \mu \mathrm{l}$ pancreas supernatant. Activity was calculated using a molar extinction coefficient of $7.1 \times 10^{-3} \mathrm{M}^{-1} \mathrm{~cm}^{-1}$. CAT activity was measured by the amount of $\mathrm{H}_{2} \mathrm{O}_{2}$ split by CAT at $37{ }^{\circ} \mathrm{C}$. The reactions were started by addition of the supernatant.

The t-GSH content was measured using the Bioxytech GSH-420 assay kit (OXIS Health Products, Inc., Portland, OR, USA). Briefly, the pancreas was suspended in $10 \mathrm{mM}$ phosphate buffer saline (PBS; pH 7.4), mixed with ice-cold $7.5 \%$ trichloroacetic acid solution and then homogenized. The homogenates were centrifuged at $3,000 \times g$ for $10 \mathrm{~min}$. The supernatant was used for the assay. The t-GSH content was measured at $420 \mathrm{~nm}$ using a spectrophotometer. This assay is based on the formation of a chromophoric thione, the absorbance of which, measured at $420 \mathrm{~nm}$, is directly proportional to the $\mathrm{t}-\mathrm{GSH}$ concentration.

LPO (malondialdehyde (MDA)) was assayed using the Bioxytech LPO-586 assay kit (OXIS Health Products, Inc.). Briefly, the pancreas was homogenized in $20 \mathrm{mM}$ PBS ( $\mathrm{pH}$ 7.4) on ice. Before homogenization, $10 \mu \mathrm{l}$ of $0.5 \mathrm{M}$ butylated hydroxytoluene in acetonitrile was added per $1 \mathrm{ml}$ tissue homogenate. After homogenization, the homogenate was centrifuged at $15,000 \times \mathrm{g}$, for $10 \mathrm{~min}$ at $4{ }^{\circ} \mathrm{C}$ and the supernatant was used for the assay. The MDA assay is based on the reaction of a chromogenic reagent, N-methyl-2phenylidole, with MDA at $45^{\circ} \mathrm{C}$. The optical density of the colored products was read at $586 \mathrm{~nm}$ using a spectrophotometer.

The protein content was measured by the Bradford method (Bradford 1976), using Protein
Quantification Kit-Rapid (Dojindo Molecular Technologies, Inc., Kumamoto, Japan).

Serum insulin was measured by the enzyme linked immunosorbent assay (ELISA) using an insulin assay kit (Morinaga Institute of Biological Science, Inc., Yokohama, Japan).

\section{Histological examination}

Tissue samples fixed in $10 \%$ formalin were embedded in paraffin. Six micrometer-thick tissue sections were prepared and stained with hematoxylineosin (HE). The size of pancreatic islets was measured using image-editing software.

\section{Statistical analyses}

Data are presented as the mean \pm standard error of the mean (SEM). The statistical significance of differences was determined by Dunnett's tests and Tukey's tests for multiple comparisons where appropriate. $\mathrm{P}<0.05$ was considered significant.

\section{Results}

Effects of radon inhalation on antioxidant-associated substances in the pancreas

SOD activity and t-GSH content in the pancreas were significantly higher and the LPO level was significantly lower in the $1000 \mathrm{~Bq} / \mathrm{m}^{3}$ group than in the control group. CAT activity was significantly higher in the $5500 \mathrm{~Bq} / \mathrm{m}^{3}$ group than in the control group (Fig. 1AD)

Effects of radon inhalation on body weight following STZ administration

Significant decreases were observed in body weight 4 days after STZ administration in Sham + STZ, $2500 \mathrm{~Bq} / \mathrm{m}^{3}+\mathrm{STZ}$, and $5500 \mathrm{~Bq} / \mathrm{m}^{3}+\mathrm{STZ}$ groups compared with the control group; however, there were no significant differences in body weight throughout the experiment between the $1000 \mathrm{~Bq} / \mathrm{m}^{3}+\mathrm{STZ}$ group and control group (Fig. 2).

Effects of radon inhalation on blood glucose and serum insulin following STZ administration

Four days after STZ administration, blood glucose was significantly higher in all groups pre-treated in the presence or absence of radon inhalation than in the control group; however, blood glucose was significantly lower in $1000 \mathrm{~Bq} / \mathrm{m}^{3}+\mathrm{STZ}$ and $5500 \mathrm{~Bq} / \mathrm{m}^{3}+\mathrm{STZ}$ 
groups than in the Sham + STZ group (Fig. 3A).

STZ administration significantly decreased serum insulin in all groups pre-treated in the presence or absence of radon inhalation compared with the control group; however, serum insulin was significantly higher in the $1000 \mathrm{~Bq} / \mathrm{m}^{3}+\mathrm{STZ}$ group than in the Sham $+\mathrm{STZ}$ group (Fig. 3B).

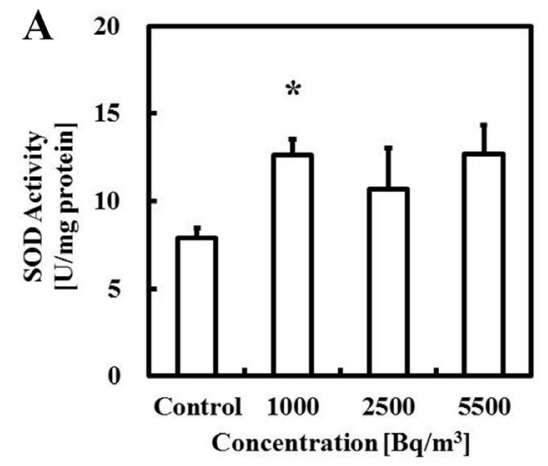

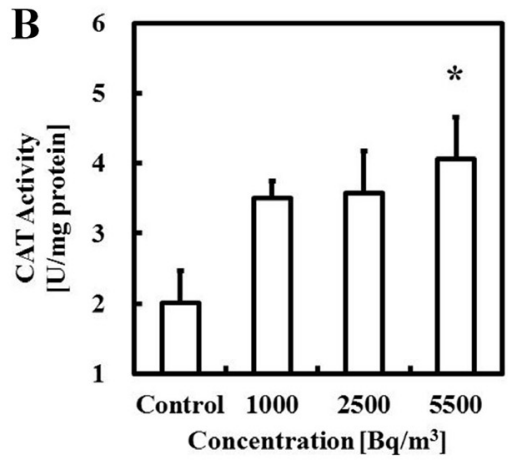

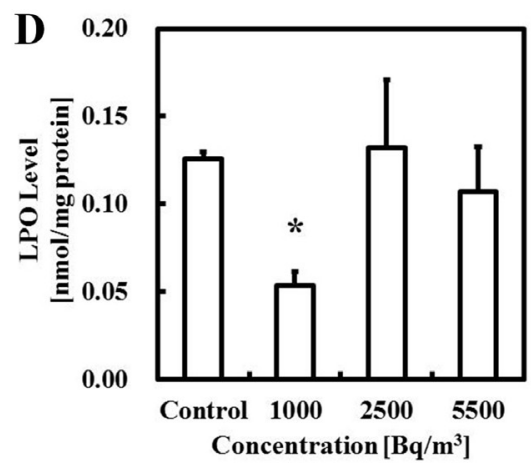

Fig. 1. Effects of radon inhalation on antioxidant-associated substances in the pancreas. (A) SOD activity, (B) CAT activity, (C) t-GSH content, and (D) LPO level in the pancreas. Each value indicates the mean \pm SEM. The number of mice per experimental point was 5-6. ${ }^{*} \mathrm{P}<0.05$, radon inhalation vs. no inhalation.
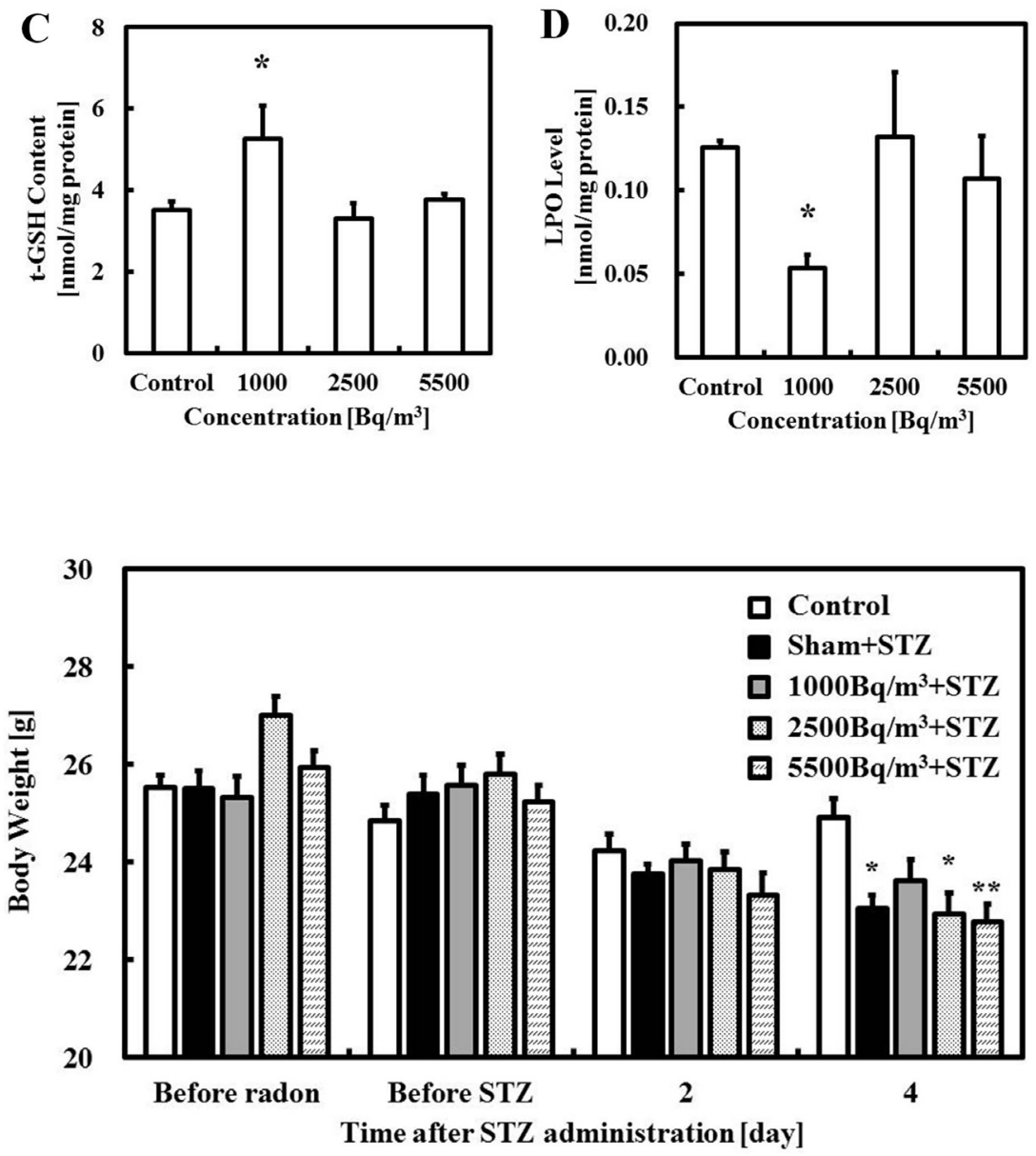

Fig. 2. Effects of radon inhalation on body weight following STZ administration. Each value indicates the mean \pm SEM. The number of mice per experimental point was 5-8. ${ }^{*} \mathrm{P}<0.05, \quad{ }^{* *} \mathrm{P}<0.01, \quad{ }^{* * *} \mathrm{P}<0.001$, radon or sham inhalation before STZ administration vs. no inhalation at the same time point. ${ }^{\#} \mathrm{P}<0.05$, ${ }^{\# \#} \mathrm{P}<0.01$, \#\#\# $\mathrm{P}<0.001$, radon inhalation before STZ administration vs. sham inhalation before STZ administration at the same time point.

\section{Histological observation}

A significant decrease in the mean size of pancreatic islets was observed in all groups pre-treated in the presence or absence of radon inhalation compared with the control group (Fig. 4A-E); however, the mean sizes of pancreatic islets were significantly larger in $1000 \mathrm{~Bq} / \mathrm{m}^{3}+\mathrm{STZ}$ and $5500 \mathrm{~Bq} / \mathrm{m}^{3}+\mathrm{STZ}$ groups than in the Sham + STZ group (Fig. 4F).
Effects of radon inhalation on antioxidant-associated substances following STZ administration

To assess the protective effect of radon inhalation on STZ-induced type-1 diabetes, antioxidant substances in pancreas were assayed (Fig. 5A-D). SOD activity and the t-GSH content were significantly lower and the LPO level was significantly higher in the Sham + STZ group than in the control group. CAT activity was 
$51 \%$ lower in the sham group than in the control group, but these differences were not significant; however, SOD activities were significantly higher in $1000 \mathrm{~Bq} / \mathrm{m}^{3}+\mathrm{STZ}$, $2500 \mathrm{~Bq} / \mathrm{m}^{3}+\mathrm{STZ}$, and $5500 \mathrm{~Bq} / \mathrm{m}^{3}+\mathrm{STZ}$ groups than in the Sham + STZ group. The t-GSH contents were significantly higher and the LPO levels were significantly lower in $1000 \mathrm{~Bq} / \mathrm{m}^{3}+\mathrm{STZ}$ and $5500 \mathrm{~Bq} / \mathrm{m}^{3}+\mathrm{STZ}$ groups than in the Sham + STZ group.

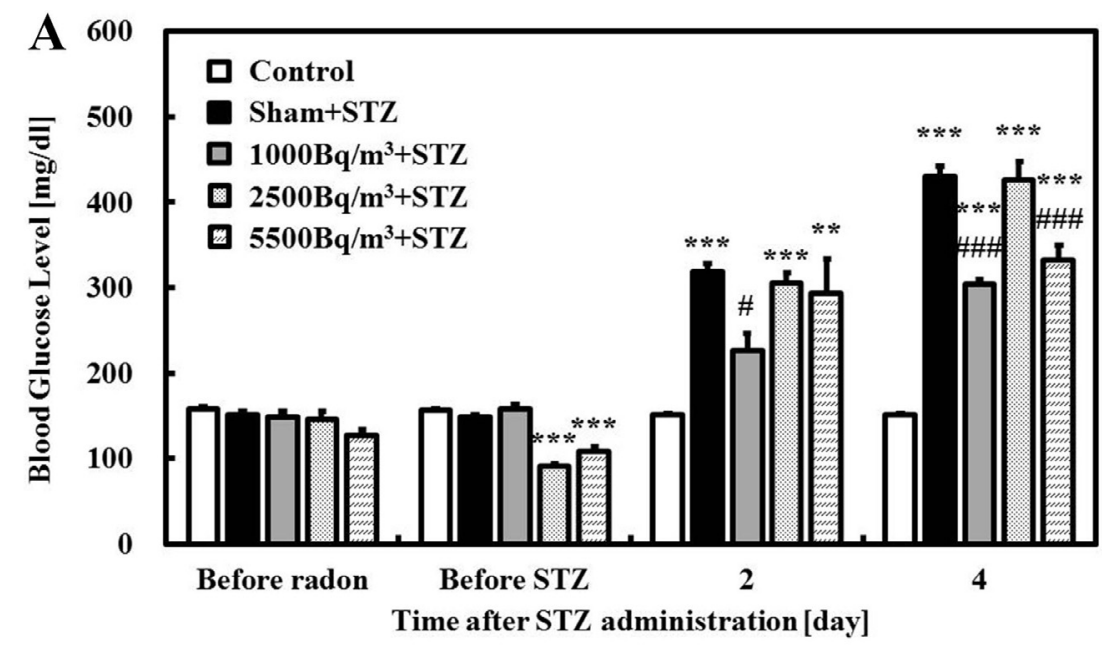

Fig. 3. Effects of radon inhalation on blood glucose and serum insulin following STZ administration. (A) Blood glucose and (B) serum insulin. Each value is the mean \pm SEM. The number of mice for each experiment and significance are the same as in Figure 2.

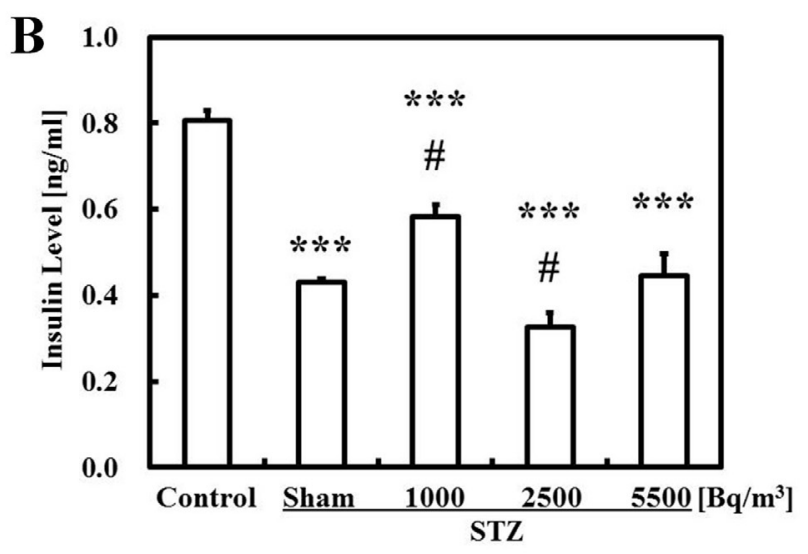

\section{Discussion}

We have reported that radon inhalation activates antioxidative functions in various organs of BALB/c strain mice (Kataoka et al. 2011b). In this study, we used C57BL/6J strain mice, which have low sensitivity to radiation compared with BALB/c (Kallman and Kohn 1956) because in this strain of mice it is especially easy to induce insulin-dependent type-1 diabetes by STZ administration (Cardinal et al. 1998); however, the effects of radon inhalation on antioxidative functions in the pancreas of $\mathrm{C} 57 \mathrm{BL} / 6 \mathrm{~J}$ strain mice have never been examined and were assessed here for the first time. Our results showed that antioxidative functions in the pancreas were significantly higher in mice that inhaled radon at doses of 1000 and $5500 \mathrm{~Bq} / \mathrm{m}^{3}$ than in control mice. These findings suggested that radon inhalation may contribute to preventing oxidative stress-related disease in the pancreas.

We examined diabetic conditions 4 days after STZ administration, considering that this is an adequate interval to induce type-1 diabetes when STZ is used. STZ administration induces permanent hyperglycemia within about 7 days and complete degranulation of $\beta$ cells is seen within 12 to 48 hrs (Lenzen 2008). In addition, metabolic alterations are usually found in animals 3 to 5 days after STZ administration (Catanzaro et al. 1994).

STZ administration induces certain typical characteristics of type-1 diabetes, such as hyperglycemia, hypoinsulinemia and body weight loss (Tomlinson et al. 1992). In the present study, all groups pre-treated in the presence or absence of radon inhalation finally showed hyperglycemia and hypoinsulinemia; however, pretreatment with radon inhalation at doses of 1000 and 
$5500 \mathrm{~Bq} / \mathrm{m}^{3}$ significantly suppressed blood glucose elevation and body weight decrease compared with the Sham + STZ group. In addition, serum insulin was significantly higher in the $1000 \mathrm{~Bq} / \mathrm{m}^{3}+\mathrm{STZ}$ group than in the Sham + STZ group. These results indicated that radon inhalation partially suppressed type-1 diabetes induced by STZ administration.
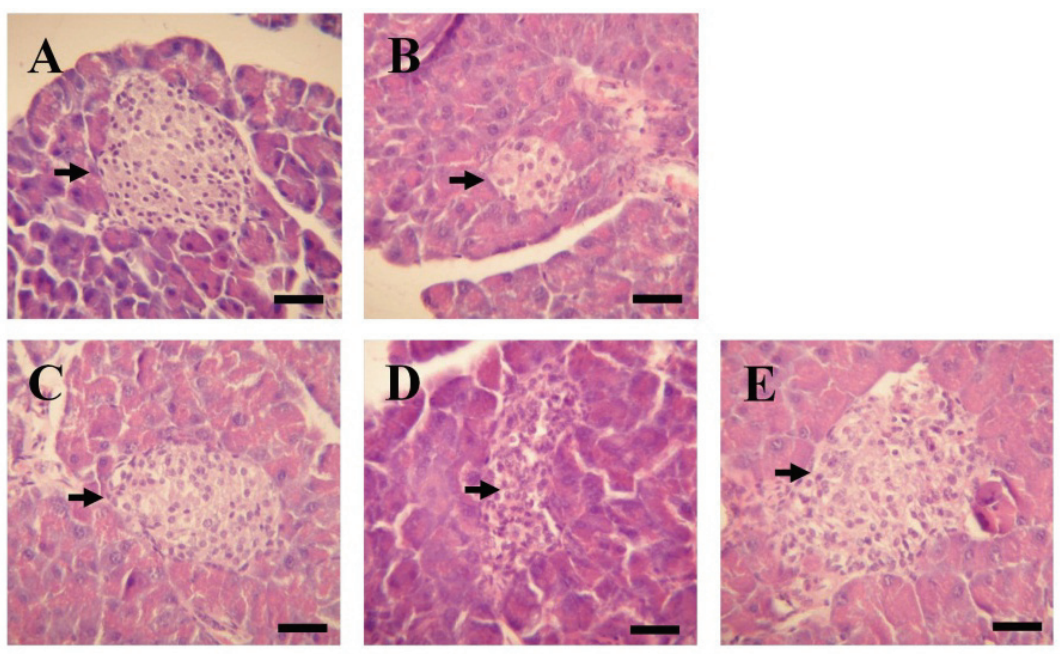

Fig. 4. Histological changes in the pancreas after STZ administration. (A) Control, (B) sham inhalation under STZ administration, (C) radon inhalation of $1000 \mathrm{~Bq} / \mathrm{m}^{3}$ under STZ administration, (D) radon inhalation of $2500 \mathrm{~Bq} / \mathrm{m}^{3}$ under $\mathrm{STZ}$ administration, and (E) radon inhalation of $5500 \mathrm{~Bq} / \mathrm{m}^{3}$ under STZ administration. Arrow indicates pancreatic islets. Scale bar $=50 \mu \mathrm{m}$. All samples were stained with H.E. (F) Larger pancreatic islets of mice pretreated with radon inhalation than those of mice treated with sham inhalation. Each value is the mean \pm SEM. The number of mice for each experiment and significance are the same as in Figure 2.

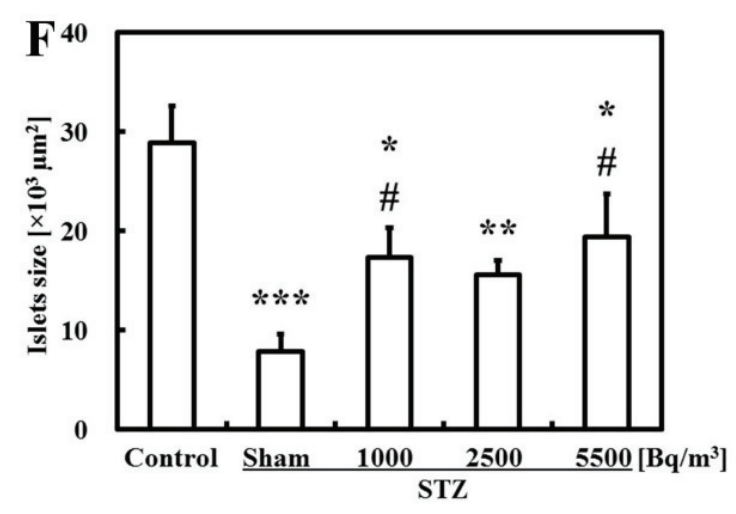

Histological observation of the pancreatic tissue further substantiated the claim that radon inhalation has protective effects on pancreatic tissue. STZ administration induced severe injury to the pancreas, such as a decrease of the islet size, which was probably due to the reduction in the number of $\beta$ cells; however, mice that inhaled radon at doses of 1000 and $5500 \mathrm{~Bq} / \mathrm{m}^{3}$ showed slight pancreatic islet damage compared with shamtreated mice.

To clarify the mechanism of radon inhalation suppressing STZ-induced type-1 diabetes, we examined antioxidative functions in the pancreas. STZ is a nitric oxide (NO) donor and NO partially restricts adenosine triphosphate (ATP) generation in mitochondria and increases xanthine oxidase (XOD) (Lenzen 2008, Szkudelski 2001). XOD catalyzes the synthesis of superoxide anion radical $\left(\mathrm{O}_{2}{ }^{--}\right)$and, as a result, $\mathrm{H}_{2} \mathrm{O}_{2}$ and hydroxyl radical $\left(\mathrm{OH}^{*-}\right)$ are formed (Szkudelski 2001). In the case of SOD deficiency or increased $\mathrm{O}_{2}{ }^{--}$production, it reacts with NO to produce peroxynitrite (ONOO), which is a highly toxic agent that can cause direct damage to proteins, lipids and DNA (Szkudelski 2001). The scavenging activity of SOD, which catalyzes the conversion of $\mathrm{O}_{2}{ }^{\circ-}$ into $\mathrm{H}_{2} \mathrm{O}_{2}$, and CAT, which transforms $\mathrm{H}_{2} \mathrm{O}_{2}$ into $\mathrm{H}_{2} \mathrm{O}$ as well as $\mathrm{GSH}$, is well known. ROS scavengers such as SOD protect $\beta$ cells against ROS attack induced by STZ administration (Kubisch et al. 1994, Robbins et al. 1980). It was reported that low-dose $\gamma$-irradiation increased SOD activity in the pancreas and suppressed $\beta$ cell apoptosis and diabetes incidence in non-obese diabetic mice (Takahashi et al. 2000). A similar result was reported in alloxan-induced type-1 diabetic rats, in which single $\gamma$-irradiation at 0.5 Gy prevented the elevation of pancreatic lipid peroxidation and blood glucose (Takehara et al. 1995). Our results showed that STZ administration caused oxidative damage, represented by decreased SOD activity and tGSH content and increased LPO in the pancreas; 
however, SOD activities and t-GSH contents were significantly higher and the LPO was significantly lower in $1000 \mathrm{~Bq} / \mathrm{m}^{3}+\mathrm{STZ}$ and $5500 \mathrm{~Bq} / \mathrm{m}^{3}+\mathrm{STZ}$ groups than in the Sham $+\mathrm{STZ}$ group. These results are consistent with the result that radon inhalation at doses of 1000 and
$5500 \mathrm{~Bq} / \mathrm{m}^{3}$ suppressed hyperglycemia. These findings suggested that radon inhalation suppressed STZ-induced type-1 diabetes through the enhancement of antioxidative functions in the pancreas.
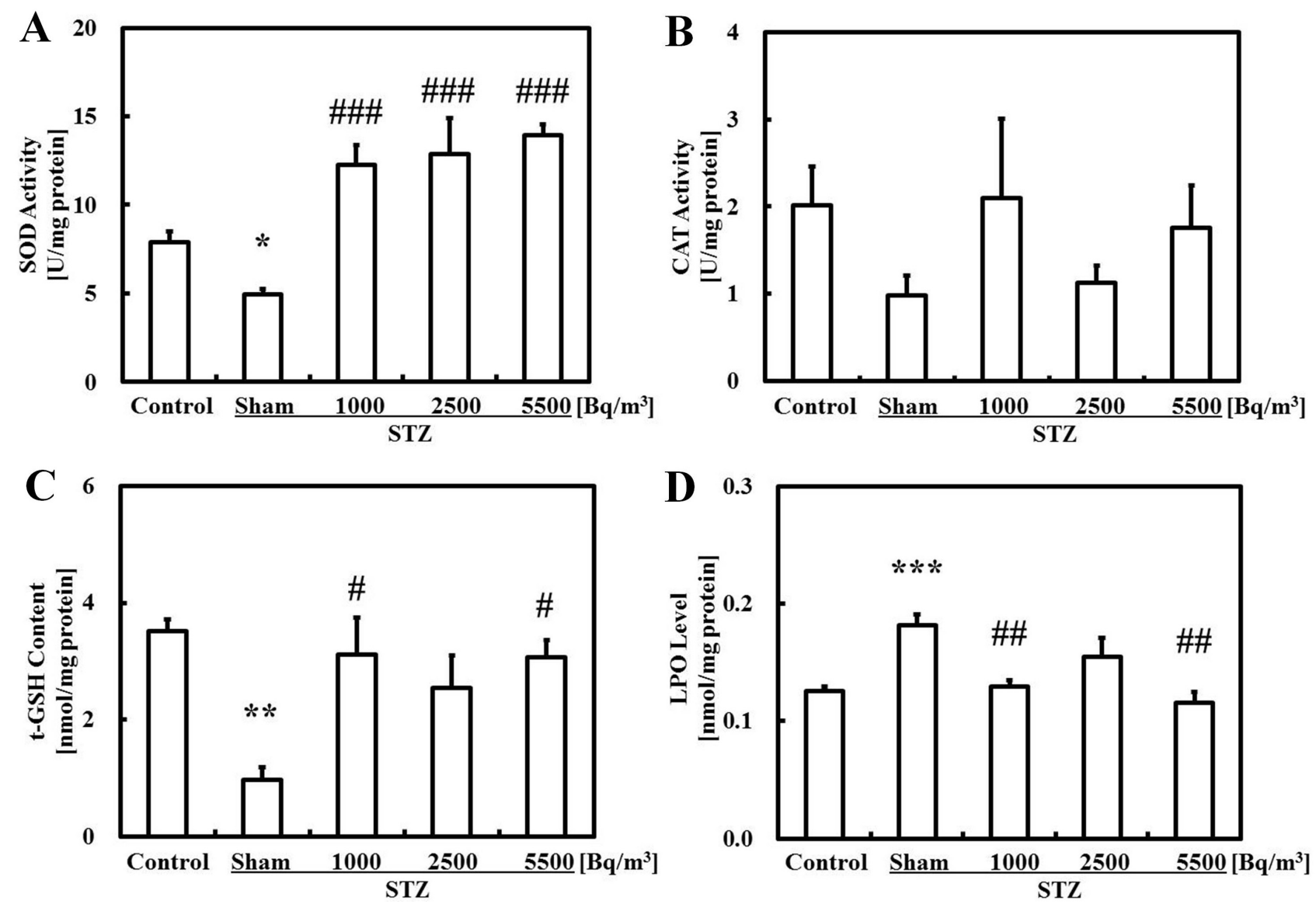

Fig. 5. Effects of radon inhalation on antioxidant-associated substances following STZ administration. (A) SOD activity, (B) CAT activity, (C) t-GSH content, and (D) LPO in the pancreas. Each value is mean \pm SEM. The number of mice for each experiment and significance are the same as in Figure 2.

It is well known that insulin is the main hormone to lower blood glucose. Although hypoinsulinemia in the $5500 \mathrm{~Bq} / \mathrm{m}^{3}+\mathrm{STZ}$ group was not improved, hyperglycemia was significantly suppressed. These findings may suggest that radon inhalation has a blood-glucose-lowering effect which is non-insulin dependent; however, no report has shown that low-dose irradiation, including radon, has such effects. It was reported that low-dose $\mathrm{X}$-irradiation enhanced the ability to regulate energy metabolism and the membrane transport mechanism, as reflected by the increase in adenosine triphosphatase (ATPase) activity (Yamaoka et al. 1994). Low-dose irradiation may contribute to the suppression of hyperglycemia through the enhancement of glycolytic metabolism in cells.
Further study is required to clarify this point.

Radon inhalation did not prevent type-1 diabetes in a dose-related fashion. We previously reported that SOD activity changes in some organs, such as the pancreas and liver, had a complex response to radon (Kataoka et al. $2011 \mathrm{~b})$. Briefly, radon inhalation of low $\left(500 \mathrm{~Bq} / \mathrm{m}^{3}\right)$ or high $\left(4000 \mathrm{~Bq} / \mathrm{m}^{3}\right)$ concentrations for $24 \mathrm{hrs}$ increased SOD activity; however, there was little change in SOD activity following the inhalation of intermediate $\left(2000 \mathrm{~Bq} / \mathrm{m}^{3}\right)$ radon concentration for $24 \mathrm{hrs}$. That is, the distinctive feature was that it had two activation points of SOD activity, although it was not clear whether the total antioxidative function, including CAT and t-GSH, changed in a similar manner with SOD, which may correlate with poor efficacy in suppressing type-1 diabetes by radon 
inhalation at a dose of $2500 \mathrm{~Bq} / \mathrm{m}^{3}$. Further study is required to understand the effects of radon inhalation on antioxidant systems in the living body.

High-level radon has been found to cause lung cancer (Lubin et al. 1995); however, based on the recommendations of the International Commission on Radiological Protection (ICRP), the risks associated with exposure to radon therapy are low. In fact, adverse effects and negative effects of radon therapy have not been reported in the past. The dose of radon absorbed under our experimental conditions was also very low according to previous reports (Franke et al. 2000, Sakoda et al. 2010), and radon inhalation has only a small risk compared to lifestyle influences, such as smoking (Sethi et al. 2012).

In conclusion, radon inhalation activated antioxidative functions in the pancreas and partially suppressed STZ-induced type-1 diabetes. The data presented in this study provide a substantial basis for future studies aimed at assessing new radon-based therapies for the treatment of type- 1 diabetes in humans.

\section{Conflict of Interest}

There is no conflict of interest.

\section{Acknowledgements}

The authors are grateful to Ms. Keiko Yamato (Graduate School of Health Sciences, Okayama University) for her technical support.

\begin{abstract}
Abbreviations
ATP - adenosine triphosphate; ATPase - adenosine triphosphatase; CAT - catalase; $\mathrm{CCl}_{4}-$ carbon tetrachloride; DNA - deoxyribonucleic acid; EDTA ethylenediaminetetraacetic acid; ELISA - enzyme linked immunosorbent assay; GSH - glutathione; HE hematoxylin-eosin; $\mathrm{H}_{2} \mathrm{O}_{2}$ - hydrogen peroxide; ICRP International Commission on Radiological Protection; LPO - lipid peroxide; MDA - malondialdehyde; NBT nitroblue tetrazolium; $\mathrm{NO}-$ nitric oxide; $\mathrm{O}_{2}{ }^{-}-$ superoxide anion radical; $\mathrm{OH}^{*^{-}}$- hydroxyl radical; ONOO - peroxynitrite; PBS - phosphate buffer saline; ROS - reactive oxygen species; SEM - standard error of mean; SOD - superoxide dismutase; STZ streptozotocin; t-GSH - total glutathione; XOD xanthine oxidase.
\end{abstract}

\section{References}

AEBI H, WYSS SR, SCHERZ B, GROSS J: Properties of erythrocyte catalase from homozygotes and heterozygotes for Swiss-type acatalasemia. Biochem Genet 14: 791-807, 1976.

ARUOMA OI: Free radicals, oxidative stress, and antioxidants in human health and disease. J Am Oil Chem Soc 75: 199-212, 1998.

BAEHNER RL, MURRMANN SK, DAVIS J, JOHNSTON RB Jr: The role of superoxide anion and hydrogen peroxide in phagocytosis-associated oxidative metabolic reactions. J Clin Invest 56: 571-576, 1975.

BRADFORD MM: A rapid and sensitive method for the quantitation of microgram quantities of protein utilizing the principle of protein-dye binding. Anal Biochem 72: 248-254, 1976.

CARDINAL JW, ALLAN DJ, CAMERON DP: Differential metabolite accumulation may be the cause of strain differences in sensitivity to streptozotocin-induced $\beta$ cell death in inbred mice. Endocrinology 139: 2885-2891, 1998.

CATANZARO OL, MARINA-PRENDES MG, HOPE SI, ZUCCOLLO A, DOMINGUEZ A: Streptozotocin-induced hyperglycemia is decreased by nitric oxide inhibition. Braz J Med Biol Res 27: 2043-2047, 1994.

CNOP M, WELSH N, JONAS JC, JÖRNS A, LENZEN S, EIZIRIK DL: Mechanisms of pancreatic beta-cell death in type 1 and type 2 diabetes: many differences, few similarities. Diabetes 54: S97-S107, 2005.

FRANKE A, REINER L, PRATZEL HG, FRANKE T, RESCH KL: Long-term efficacy of radon spa therapy in rheumatoid arthritis-a randomized, sham-controlled study and follow-up. Rheumatology 39: 894-902, 2000.

HARJUTSATO V, SJÖBERG L, TUOMILEHTO J: Time trends in the incidence of type 1 diabetes in Finnish children: a cohort study. Lancet 371: 1777-1782, 2008.

ISHII K, YAMAOKA K, HOSOI Y: Enhanced mitogen-induced proliferation of rat splenocytes by low-dose wholebody X-irradiation. Physiol Chem Phys Med NMR 27: 17-23, 1995.

ISHIMORI Y, MITSUNOBU F, YAMAOKA K, TANAKA H, KATAOKA T, SAKODA A: Primary functions of the first Japanese large-scale facility for exposing small animals to radon. Jpn J Health Phys 45: 65-71, 2010. 
ITO M, KONDO Y, NAKATANI A, HAYASHI K, NARUSE A: Characterization of low dose streptozotocin-induced progressive diabetes in mice. Environ Toxicol Pharmacol 9: 71-78, 2001.

KALLMAN RF, KOHN HI: The influence of strain on acute X-ray lethality in the mouse. I. LD50 and death rate studies. Radiat Res 5: 309-317, 1956.

KATAOKA T, NOMURA T, WANG DH, TAGUCHI T, YAMAOKA K: Effects of post low-dose X-ray irradiation on carbon tetrachloride-induced acatalasemic mice liver damage. Physiol Chem Phys Med NMR 37: 109-126, 2005.

KATAOKA T, MIZUGUCHI Y, YOSHIMOTO M, TAGUCHI T, YAMAOKA K: Inhibitory effects of prior low-dose $\mathrm{X}$-irradiation on ischemia-reperfusion injury in mouse paw. J Radiat Res 48: 505-513, 2007.

KATAOKA T, NISHIYAMA Y, TOYOTA T, YOSHIMOTO M, SAKODA A, ISHIMORI Y, AOYAMA Y, TAGUCHI T, YAMAOKA K: Radon inhalation protects mice from carbon-tetrachloride-induced hepatic and renal damage. Inflammation 34: 559-567, $2011 \mathrm{a}$.

KATAOKA T, SAKODA A, ISHIMORI Y, TOYOTA T, NISHIYAMA Y, TANAKA H, MITSUNOBU F, YAMAOKA K: Study of the response of superoxide dismutase in mouse organs to radon using a new largescale facility for exposing small animals to radon. J Radiat Res 52: 775-781, $2011 \mathrm{~b}$.

KATAOKA T, NISHIYAMA Y, YAMATO K, TERAOKA J, MORII Y, SAKODA A, ISHIMORI Y, TAGUCHI T, YAMAOKA K: Comparative study on the inhibitory effects of antioxidant vitamins and radon on carbon tetrachloride-induced hepatopathy. J Radiat Res 53: 830-839, 2012.

KOJIMA S, MATSUKI O, KINOSHITA I, GONZALEZ TV, SHIMURA N, KUBODERA A: Does small-dose $\gamma$-ray radiation induce endogenous antioxidant potential in vivo? Biol Pharm Bull 20: 601-604, 1997.

KOJIMA S, MATSUKI O, NOMURA T, YAMAOKA K, TAKAHASHI M, NIKI E: Elevation of antioxidant potency in the brain of mice by low-dose $\gamma$-ray irradiation and its effect on 1-methyl-4-phenyl-1,2,3,6tetrahydropyridine (MPTP)-induced brain damage. Free Radic Biol Med 26: 388-395, 1999.

KOJIMA S, NAKAYAMA K, ISHIDA H: Low dose gamma-rays activate immune functions via induction of glutathione and delay tumor growth. J Radiat Res 45: 33-39, 2004.

KUBISCH HM, WANG J, LUCHE R, CARLSON E, BRAY TM, EPSTEIN CJ, PHILLIPS JP: Transgenic copper/zinc superoxide dismutase modulates susceptibility to type 1 diabetes. Proc Natl Acad Sci U S A 91: 9956-9959, 1994.

LENZEN S, DORINKGERN J, TIEDGE M: Low antioxidant enzyme gene expression in pancreatic islets compared with various other mouse organs. Free Radic Biol Med 20: 463-466, 1996.

LENZEN S: The mechanisms of alloxan- and streptozotocin-induced diabetes. Diabetologia 51: 216-226, 2008.

LUBIN JH, BOICE JD Jr, EDLING C, HORNUNG RW, HOWE GR, KUNZ E, KUSIAL RA, MORRISON HI, RADFORD EP, SAMET JM, TIRMARCHE M, WOODWARD A, YAO SX, PIERCE DA: Lung cancer in radon-exposed miners and estimation of risk from indoor exposure. J Natl Cancer Inst 87: 817-827, 1995.

MAYER-DAVIS EJ, BEYER J, BELL RA, DABELEA D, D'AGOSTINO R Jr, IMPERATORE G, LAWRENCE JM, LIESE AD, LIU L, MARCOVINA S, RODRIGUEZ B; SEARCH FOR DIABETES IN YOUTH STUDY GROUP: Diabetes in African American youth: prevalence, incidence, and clinical characteristics: the SEARCH for Diabetes in Youth Study. Diabetes Care 32 (Suppl 2): S112-S122, 2009.

MITSUNOBU F, YAMAOKA K, HANAMOTO K, KOJIMA S, HOSAKI Y, ASHIDA K, SUGITA K, TANIZAKI Y: Elevation of antioxidant enzymes in the clinical effects of radon and thermal therapy for bronchial asthma. J Radiat Res 44: 95-99, 2003.

NISHIYAMA Y, KATAOKA T, TERAOKA J, SAKODA A, ISHIMORI Y, YAMAOKA K: Inhibitory effects of pre and post radon inhalation on carbon tetrachloride-induced oxidative damage in mouse organs. Radioisotopes 61: 231-241, 2012.

ROBBINS MJ, SHARP RA, SLONIM AE, BURR IM: Protection against streptozotocin-induced diabetes by superoxide dismutase. Diabetologia 18: 55-58, 1980.

SAKODA A, ISHIMORI Y, KAWABE A, KATAOKA T, HANAMOTO K, YAMAOKA K: Physiologically based pharmacokinetic modeling of inhaled radon to calculate absorbed doses in mice, rats, and humans. $J$ Nucl Sci Technol 47: 731-738, 2010. 
SETHI TK, EL-GHAMRY MN, KLOECKER GH: Radon and lung cancer. Clin Adv Hematol Oncol 10: 157-164, 2012.

SHERTZER HG, SCHNEIDER SN, KENDIG EL, CLEGG DJ, D'ALESSIO DA, JOHANSSON E, GENTER MB: Tetrahydroindenoindole inhibits the progression of diabetes in mice. Chem Biol Interact 177: 71-80, 2009.

SZKUDELSKI T: The mechanisms of alloxan and streptozotocin action in B cells of rat pancreas. Physiol Res 50: 537546, 2001.

TAKAHASHI M, KOJIMA S, YAMAOKA K, NIKI E: Prevention of type 1 diabetes by low-dose gamma irradiation in NOD mice. Radiat Res 154: 680-685, 2000.

TAKEHARA Y, YAMAOKA K, HIRAKI Y, YOSHIOKA T, UTSUMI K: Protection against alloxan diabetes by lowdose ${ }^{60} \mathrm{Co} \gamma$ irradiation before alloxan administration. Physiol Chem Phys Med NMR 27: 149-159, 1995.

TOMLINSON KC, GARDINER SM, HEBDEN RA, BENNETT T: Functional consequences of streptozotocin-induced diabetes mellitus, with particular reference to the cardiovascular system. Pharmacol Rev 44: 103-150, 1992.

YAMAOKA K, EDAMATSU R, MORI A: Increased SOD activities and decreased lipid peroxide levels induced by low dose X irradiation in rat organs. Free Radic Biol Med 11: 299-306, 1991.

YAMAOKA K, ISHII K, EDAMATSU R, ITO T, MORI A: Changes in specific amino acid residues and $\mathrm{Na}^{+}, \mathrm{K}^{+}-$ ATPase activity in cell membranes of rat cerebral cortex by low dose X-irradiation. Physiol Chem Phys Med NMR 26: 323-328, 1994.

YAMAOKA K, KOJIMA S, NOMURA T: Change of SOD-like substances in mouse organs after low-dose X-ray irradiation. Physiol Chem Phys Med NMR 31: 23-28, 1999.

YAMAOKA K, KATAOKA T, NOMURA T, TAGUCHI T, WANG DH, MORI S, HANAMOTO K, KIRA S: Inhibitory effects of prior low-dose X-ray irradiation on carbon tetrachloride-induced hepatopathy in acatalasemic mice. J Radiat Res 45: 89-95, 2004a.

YAMAOKA K, MITSUNOBU F, HANAMOTO K, MORI S, TANIZAKI Y, SUGITA K: Study on biologic effects of radon and thermal therapy on osteoarthritis. J Pain 5: 20-25, $2004 \mathrm{~b}$.

YAMAOKA K: Activation of antioxidant system by low dose radiation and its applicable possibility for treatment of reactive oxygen species-related diseases. J Clin Biochem Nutr 39: 114-133, 2006.

YOSHIMOTO M, KATAOKA T, TOYOTA T, TAGUCHI T, YAMAOKA K: Inhibitory effects of prior low-dose Xirradiation on cold-induced brain injury in mouse. Inflammation 35: 89-97, 2012. 